\title{
Childrens Views of Documentation in the Relations between Home and School
}

\author{
Ann-Marie Markström \\ Linköping University Post Print
}

Tweet

N.B.: When citing this work, cite the original article.

Original Publication:

Ann-Marie Markström, Childrens Views of Documentation in the Relations between Home and School, 2015, Children \& society, (29), 3, 231-241.

http://dx.doi.org/10.1111/chso.12114

Copyright: Wiley: 24 months

http://eu.wiley.com/WileyCDA/

Postprint available at: Linköping University Electronic Press

http://urn.kb.se/resolve?urn=urn:nbn:se:liu:diva-117783 
2014-08-21

\title{
Children's views of documentation in the relations between home and school
}

\author{
Ann-Marie Markström
}

\begin{abstract}
The aim of the article is to shed light on children's views of the different forms of documentation that are related to and used in the interaction between home and school. The study draws on qualitative interviews with 52 pupils aged 12-13 years in Year 6 in Sweden. The analyses reveal how documentation and documents are created and understood from the pupils' perspectives. The pupils point to how documentation form an important part of the communication between home and school and how documents are produced, communicated and consumed by the different actors and their own role.
\end{abstract}

Keywords: home and school relations, documentation, pupil perspective

\section{Introduction}

There has been an increased requirement for documentation in the communications between the welfare state's various institutions and its citizens, which in turn reflects the increased possibilities in and with the digitalisation of society. Our lives are constantly documented. Even before we are born we are subject to controls and documentation at the maternity clinic - which are then followed by controls at the post-natal clinic, child health centre, preschool and school. In the school context, documentation is often used as a tool, mainly in connection with the assessment of children's performances. Documentation is also widely used in the communications and collaboration between school and parents (guardians).

In Sweden, parental involvement has become more important as a result of political and ideological tendencies to document and evaluate individuals and competing schools. New ideas about children's development and learning and the question of parental influence in school have contributed to cooperation between home and school being regarded as part of teachers' and parents' duties (Sarmento and Freire, 2012; Markström, 2013).Communications between home and school can take different forms, not least through different types of documentation relating to individual pupils where documents are used to show, prove and 
explain the different relationships found in school. How this documentation is created, reproduced and used in practice in school has not been studied in depth, and especially not from the children's/pupils' perspective. In this paper, the focus is on what children think about the relations between home and school and how they perceive and understand the use of different documents in the interactions between home and school.

What forms of documentation is constructed in the relation between home and school and what influence do children have in this process?

This article is based on a qualitative study of pupils' experiences and views of the relation between home and school and how documents and documentation form an important part of the communication.

\section{Communication between home and school}

In studies of home-school relations pupils are often regarded as passive recipients and as objects for the adults', teachers' and parents' relations. Parents have been allowed to speak for their children (Edwards and Alldred, 2000; Vyverman and Vettenburg, 2009; Saramento and Freire, 2012) and most previous research does not consider children's views or role in home-school relationships. However, some studies have a more critical perspective and are based on the children's own views and experiences. Some studies show that children's and young people's approaches to collaboration and relations between home and school can affect how these are constructed in practice (Edwards et al., 2000; Deslandes and Cloutier, 2002; Vyverman and Vettenburg, 2009; Markström 2013). According to some researchers, children have a negative view of parents' participation in school activities or of parent-teacher interactions, because these are often associated with teachers' complaints about them (Lawson, 2003; Markström 2013). In Vyverman and Vettenburg's (2009) study of the attitudes of 10-year-old children to their parents' participation at school, these are shown to be related to the extent to which parents participate and how children influence their parents' relations with school. Furthermore, their study shows that most children's views about parental involvement in school depend on how such involvement affects them as individuals.

Nowadays there are increased possibilities for contact between the actors at home and at school, for instance by the use of text messages or digital systems. In Castelli and Pieri's (2007) study of the attitudes of parents, teachers and students to mobile-mediated homeschool partnerships, they show that mobile phones are perceived as tools for effective, quick 
and necessary communication. However, the children feel that this technology is "a real violation of their privacy and an intrusion in the child-parent relationship" (ibid. 2007, p. 186)

\section{Pupils in the audit and documentation society}

Power (1997) maintains that comparisons of performance and different types of inspection constitute the core of an "audit society". As an institution with which all children and parents come into contact, the school constitutes a central part of an examination society's practices, where different expectations are to be realised. By means of exams, tests, development discussions and so on the present situation is controlled and accounted for. These descriptions have to be based on "facts", where control also has a sorting function; something that characterises the education system. From the perspective of an "examination society" the school's use of different types of documents can be seen as productive and normalising practices (cf. Alasuutari, Markström and Vallberg Roth, 2014; Markström, 2011) that create and re-create truths, and where dominating mindsets and power are created, negotiated and communicated based on what is required by those occupying these arenas (Rose, O`Malley and Velverde, 2006). In the school, teachers, pupils and parents make their own contributions to the compulsory examination process, at the same time as they are also subject to examination (Markström 2009, 2011). People are therefore not passive in these processes, but take part in this control - a form of self-regulation (Foucault, 1991; Rose, OMalley and Velverde, 2006).

The influence of the discourses is both direct and indirect and constitutes a "softer" form of control (Foucault, 1991; Rose, O’Malley and Velverde, 2006), i.e. forms that do not appear as an exercise of power in terms of open control or examination (Foucault, 1991; Rose, 1999; Markström, 2011; Bartholdsson, 2012). Instead, it is more about individuals focusing on improvement projects with a democratic striving for consensus and where the individual is given a position (as actor) in the organisation or structure, such as the partner in a pupil, parent and school relation. In this process, individuals participate in terms of being selfreflecting, motivated and responsible, and different forms of documents have come to play a greater role. But what is the function of documents and documentation for the different actors, and what kind of agency do they have in school and in the relation between home and school? 


\section{Documents in action}

The school can be regarded as a world of texts and as a documentation culture (Andreasson and Asplund Carlsson, 2009). This world and this culture consist of textbooks and other printed teaching aids, different types of steering documents and descriptions of aims and objectives, as well as documents that are created and re-created in school and that concern the pupils. Such documents can take different forms and be used in a multitude of different contexts and for different purposes. Arguments for well-documented pupils can be to identify weaknesses and problems that need to be rectified, to remove different kinds of obstacles, and to safeguard against and prevent problems.

Documents have a tendency to fix categorisations and labels - also known as freezing the phenomena, and thereby have an ongoing active and productive role. This can apply to documents that are used in different institutional practices, such as the school, health care etc. For example, if a person has received a diagnosis, this documented label will be important in future encounters and documentation and cannot be disregarded.

In this way documentation becomes a "natural part" and has importance for the interactions between people, and in school, especially in terms of the constitution of pupils and their everyday lives. The question in focus in this article is thus how pupils see their own roles in relation to documents and documentation in the context of the relations between home and school.

The starting point for the article is that materialities, such as textual or digital documents, are produced by people and appropriated by them. However, other perspectives have also inspired the analysis. One way of understanding the role that material, such as texts, documents and other artefacts, plays is to use Actor-network theory (ANT), a theoretical perspective that problematises the significance of the material in our understanding of how we create "reality" (Latour 2005). ANT presupposes that networks of human and non-human actants and materialities construct our reality. Such networks of human actors and materialities can be institionalised phenomena, such as rituals (marriage, examinations), or organisations that are created for different purposes, e.g. educational institutions. Or, as Latour puts it (2005, p. 71), "anything that modifies a state of affairs by making a difference is an actor". That is, documentation and documents can be seen as agentic in social interactions and in institutional practices. 
In this perspective, inscriptions, such as texts, documents and so on can be seen as important actants that stabilise relations, roles and functions, e.g. in an organisation like the school or in home-school relations (cf. Alasuutari, Markström and Vallberg-Roth, 2014). These inscriptions can be distributed and moved in time and space between different contexts and actants, i.e. a text that is created in one context is used in another context and thereby creates new inscriptions.

Within an organisation (such as the school) different types of texts and documents function and "act" in a way that cannot really be replaced by anything or anyone else. The material and the discursive are closely interwoven and intra-active and can create a powerful version of social reality (Atkinson and Coffey 2011). This perspective means that instead of seeing documents as passive, taken-for-granted objects, in this study they are seen as relationally created and in process, i.e. as both products of relations and as co-producers.

\section{A Swedish case study - a pupil perspective}

In this section the results of interviews with pupils aged 11-12 years in a Swedish secondary school are presented. In the Swedish school regular documentation is a legal requirement. One example is that teachers have to make regular assessments of each pupil, and that this information has to be communicated to the pupil and his or her parents (Lgr 11). Previous research shows that it is not only pupils' knowledge and learning that is documented, but also assessments of their behaviour, personality and attitudes (Andréasson \& Asplund Carlsson, 2009; Bartholdsson, 2012). These assessments have to be done every term in the earlier school years, because in these years grades are not given. In Year 6 and onwards grades are given in the Swedish school, which means that these written assessments do not need to be as frequent.

If a pupil needs extra support this has to be documented in an action plan - in which the problem is described, the type of support noted, and who is to take responsibility for the child reaching the desired target named. This type of documentation can be regarded as identitycreating texts that can be read, interpreted and used in different ways each time they are consulted. In short, these are documents about pupils that create and re-create their identities (Andréasson and Asplund Carlsson, 2009) and are to be shared with parents and guardians at home. This communication can take the form of textual, digital and hand-written documents, 
such as information sheets, contact books, different types of certificates or other documents that have to be signed, text messages and communications via the Internet. All these documents can be regarded as institutionalised forms of communication - between the different actors in school and with those outside school.

Direct encounters in the form of development discussions also take place, in which parents, pupils and teachers meet to talk about the pupils' progress at school. Different kinds of written data are often used in these meetings, e.g. information from teachers about the pupil's performance in the various subjects, and written notes for the teacher who is to lead the discussion. In addition, different kinds of forms sometimes have to be filled in by pupils or parents before or during the discussion. The type of discussion and how it is to be conducted is usually determined by the school in question.

\section{The study}

In this study 52 audio-recorded semi-structured interviews with 23 boys and 29 girls from Year 6 (11-12 years) in a Swedish secondary school were conducted. In the article the pupils' utterances about the different types of communication between home and school are analysed, with a focus on documents and documentation (in different forms) and how these are created and understood from the pupils' perspectives (James, 2007). In this research, and from a relational view of childhood, the competent child is seen as competing with other discourses. In other words, children own their experiences of and thoughts about school, schooling and home-school relations. However, as children vary in age and gender, and come from families with different backgrounds, they are obviously not a homogenous group. Children will thus have different opinions depending on their experiences of home and school and the school context in which they find themselves

The interviews were conducted in seven schools in Sweden. The children came from the low to middle income areas of two cities and had different economic, ethnic and social backgrounds. The interviews were conducted in the school after obtaining informed and written consent from the children and their parents, in accordance with ethical research standards. In the meetings with the individual child the voluntary nature of participation was also emphasised (cf. Harcourt, Perry and Waller, 2011).

The interviews were related to the children's experiences of and thoughts about the cooperation and relations between home and school, and, more specifically, between the 
children, their parents and their teachers. Among other things, the questions covered their experiences of and thoughts about the extent of the relations between home and school, the forms of interaction and communication that took place between them, how the different types of documentation were used in these relations and their own roles in these interactions.

The children's responses to the questions posed in the interviews were transcribed verbatim by the author. The analysis is influenced by critical discourse analysis, which takes its point of departure in the ideas and utterances that are expressed and reproduced through language (Jørgensen and Philips, 2002). In the analysis, attention is paid to the discursive aspects of the children's accounts of their experiences of and thoughts about home and school relations in relation to documentation.

A close, empiric and open-reading coding was both associated with and tested by tentative theoretical questions and interpretations. In the first stage the content and phrases were categorised. The material was then investigated in relation to the research questions. The second stage involved analysing the different accounts of the relations and the documentation. This focused on key themes showing dominant and deviant statements and centred on how documentation and documents are talked about in the narratives and how the children understand the relations in the intermediate domain (Mayall, 2002) between home and school.

For example, many Swedish municipalities now use digital software to register absence from school. Such systems can mean that if a child is late, or if his or her absence has not been notified in advance, the child is registered in the system and a text message sent direct to the parents. Parents can also access the system and see what has been registered for their particular child (Bodén, 2013).

\section{The production, transmission and consumption of documents in the pupils' views}

In order to capture the children's understanding and experience of the cooperation between home and school, they were first of all asked to give examples of how the relations between home and school were expressed in their own cases. Most of the children's examples of the contact between their parents and teachers can be regarded as typical for the Swedish school context: log books/contact books, individual developmental plan meetings, telephone calls, text-messages and questionnaires (on paper), e-mails, parents' visits to the classroom and parents' evenings. Some of these contacts and activities involved all parents (information 
sheets, information on the Internet, parents' nights etc), although the majority concerned the pupil as an individual at school or at home.

In the interviews with the pupils it is clear that many of them, at a general level, know who the senders and recipients of the different kinds of documents relating to school are. From the pupils' narratives it can be ascertained that it is the school, and primarily the teacher, that is the initiator or producer of the different kinds of documents they come in contact with; first and foremost in the everyday world of school, but also with regard to the relation between home and school, which is the focus of this article. Other adults, such as the principal, school nurse and parents, are also involved in the "production" and "consumption" of documents. The role of the pupils themselves is also important in this context. In the following, the pupils' own narratives concerning the production, distribution and consumption of the different documents in relation to the interaction between home and school, their own role and what they think about documentation in this context are presented.

\section{Producing documents}

In the interviews the pupils say that in their experience much of the contact that takes place between home and school is facilitated by the different kinds of documents that are produced in school. What they highlight as examples, and which they themselves are sometimes involved in, are documents in the form of printed or hand-written papers. Some of these documents are produced and communicated without any face-to-face contact between the school and the home. This mainly applies to documents that are produced by the school, and primarily by the teachers, in the form of information sheets, timetables, forms that the parents have to fill in, reminders that the child needs to take something to school, contact books in which the teacher has written a message and so on. But the pupils also talk about texts that they have co-produced, e.g. papers relating to tests or exams that they have done and that need to be signed by the parents in order to certify that they have been notified of their child's results. Several pupils also mention new texts that they have been asked to write in their logbooks - notebooks that pupils have to show to their parents - about their school day, i.e. a documentation of the pupils' working week. Teachers can also ask pupils to write specific things in their logbooks, such as messages that the teacher writes up on the whiteboard, or more free-flow descriptions of their week in school. The following quotation is from one of the interviewed pupils: 
Benjamin: We usually have to write in our logbooks every Friday. The teacher usually writes the subject on the whiteboard. We then have to write about what we've done during the week what I've done in maths or about a theme or such like and how much I managed to do. Today I wrote that we had a maths test and that I had done everything that we were supposed to do in Swedish.

A-M: What is supposed to be written in the logbook; what is it for?

Benjamin: What we have done and stuff like that. We write about what we've done every Friday and then take it home. Mum has to read it and sign it. But I don't write very much, and sometimes forget it, to take it home, which is a bit of a bother.

A-M: Why does she have to sign it?

Benjamin: To confirm that she's read it (um) and that I've shown it to her.

Here, Benjamin says that "we" usually write something, which can be interpreted as the group as a whole writing, although it is clear from the quote that what the teacher writes on the whiteboard has to be copied and included - a co-production of text. Here he does not explain any specific function for the practice but more of a routine without meaning, a routine that he also sometimes seems to resist. A number of documents are thus produced on a daily basis and form part of the home-school relation: those produced by the school/teacher, those produced by the pupils themselves, those produced by the teacher and that the pupils copy.

In some cases the pupils say that they and their parents have to sign a paper (document) if anything specific has been agreed on. Cecilia says that she has reading and writing difficulties and that after pressure from her parents now receives help from a remedial teacher:

Cecilia: I have difficulty with reading, it's not that easy.

Interviewer: I see, did you talk about this (reading and writing difficulties) during the development discussion?

Cecilia: Yes, and Mum and Dad have to sign the paper about what has to be done.

Interviewer: Is it a kind of action plan?

Cecilia: Yes, that's what it's called, papers that have to be signed so that I can get help. Before that I had to do lots of tests and write things down for the principal. My mother wanted me to have it and the principal arranged it. My friend got it as well later. We get extra help now.

In this extract Cecilia shows that she knows what kind of documentation is necessary in order to get remedial help at school. The institutionally led practice is here described as a practice 
in which the parents 'have' to be involved and the girl describes her own role more like an object of the practice.

In an institution like school, a number of categories and terms are used that also have to be documented. In order to get remedial help in the Swedish school a so-called pedagogic investigation is required. The pupil, teacher, remedial teacher and parents are all involved in this investigation, which can result in a remedial programme consisting of a number of different documents (e.g. assessments, tests by different professionals in school. That is, a written assessment of a pupil can be produced and used by different professions in one context and then used later in another, to diagnose and to judge and in collaboration with different actors, that are later followed up and again documented.

In the examples above the pupils seem to describe themselves as objects rather than active subjects of the practice.

However, in most cases it is the school that initiates these activities and contacts between the home and the school. Also, some of the activities in which the children are involved take place in their homes rather than in school. In some of the interviews the children say that contact can be initiated by the home in terms of telephone calls, text messages, emails, and, in some cases, written messages on paper. If contact books are used some parents write messages for the teacher in them, i.e. texts and documents are also produced in the home. Examples given by the children are information about the child's health, notification of an appointment with a doctor, confirmation of time off from school etc.

The pupils also talk about documents that they have initiated themselves. These refer to receiving help with something where parents need to "endorse" these needs, e.g. if for some reason they need to be excused from attending a PE lesson.

Christine: I've been ill a lot and have been unable to take part in orienteering, so I forced my Mum to write a note. The PE teacher doesn't believe me. We have to have to have some kind of written confirmation, but Mum doesn't always want to write a note because she finds writing difficult, and that they don't believe me.

In this example Christine talks about how she makes use of her parents and the expected written document in order to reach a goal, namely to be excused from an activity in school when she is unwell. The school's routines require the production of written confirmation 
from parents as to why this is necessary. In this example the pupil is the initiator who, together with her mother, creates a document for a specific purpose (the document makes a difference, cf. Latour, 2005). That is, the function of documentary practices as a support which enables the pupils to gain influence in the school.

Some pupils do not want their parents to be involved in their school work, e.g. tests or other things done at school. For example, they say that they feel criticised and vulnerable when they have to take their corrected test home for signing. Some think that it is "not necessary to take it home, the test has already been done". One pupil confesses that "I usually forget to take all the papers home" (in the sense of intentionally "forgetting").

To sum up, there seem to be a heterogeneous body of documents which fulfil different functions in transmitting information between home and school. Furthermore, both the production of documents and the consequences of this activate different parties at school and in the home. From the interviews it is clear that the pupils play an important role, but do not always experience that they have any influence in this work. The examples of documents that are produced, as outlined by the pupils above, can be interpreted as having different purposes and functions: to make a pupil visible, to highlight the school and its rules, to control a course of events, to control and involve different actors.

\section{Children positioned as distributers and communicators of documents}

The children's sense of being used as messengers between the school and the home is typical in the interviews. The children point out that they are expected to carry messages about their schoolwork and performance at school, information, logbooks and forms home to their parents. They also say that they co-produce many of the documents that they distribute between the home and the school, that they have little influence over them and that they simply act as messengers. However, the interviewed pupils feel differently about telling their parents about things like exam results. Some say that they think it is good that their parents know what they are doing and what kind of progress they are making at school, for example by taking their corrected tests home for their parents to sign, or going through their documented performances with their parents in development discussions. Other pupils are unhappy about this kind of exposure and information transfer, and say that they can take care of their school situation without too much interference from their parents. In the interviews 
there are also examples of pupils saying that they take it upon themselves to decide whether or not to write in their logbooks or to give different kinds of documents to their parents. Some pupils say that they can easily sort things out with their teachers, and that certain documents can cause parents unnecessary alarm. In one case, a pupil said that he tries to "protect" his parents by not giving them all the papers that he receives from the teacher and is expected to take home. His parents cannot speak Swedish and "are stressed out when they get too many papers". This also applies to Emma:

\footnotetext{
Emma: The teacher sends a lot of information, forms and stuff, every week. My mother says "God, there is too much paper". She thinks it is too much.

Interviewer: What do you think about that?

Emma: I think that they don't have to tell parents everything. We can deal with it in school. I can manage, why should they [parents] bother?
}

This variation shows that the pupils take different positions in the border area between public and private. Documentation also becomes an important actant in the family processes and dynamics.

In the schools in which this interview study was carried out, the pupils mainly referred to paper-based documentation between the home and school, although they did acknowledge that digital documentation existed but apart from teachers and parents using email to communicate with each other they knew little about it. They also said that a system should be introduced so that absence from school could be registered and communicated digitally between home and school. Such a system means that information about and the documentation of e.g. absence is immediately communicated to parents and can re-appear at a later stage in connection with the pupil's grade, where the number of hours of absence is indicated (cf. Bodén, 2013).

The distribution and communication of documents between the home and school can thus take place online and off-line. In this interview study the pupils say that they are positioned and act as messengers by carrying documents backwards and forwards. In this way documents can travel between the various actors and create activity, i.e. serve as an actant for several people and contribute to the construction and re-construction of the social order in the context of the school (cf. Atkinson and Coffey, 2011). Their role in this process means that the pupils themselves and the school are made visible, and that they are made aware of what 
is communicated between home and school, at least with regard to the paper texts that the teachers, parents and pupils produce.

\section{Addressees and consumption}

The (materially) produced documents (textual, digital etc.) that the pupils talk about in the interviews can in the first instance be seen to have a clear addressee - pupil, parent or teacher - and can be interpreted, understood and consumed/used in various ways. In other words, the documents can be regarded as non-human actants (Atkinson and Coffey, 2011) in the interaction between home and school.

The addressees can also be more diffuse in terms of time and space, in that narratives are created and re-created in documents and can be disseminated and be used by other addressees. In the following excerpt Anna talks about a text that was not intended for an adult at all:

Anna: My teacher showed my mother a note that I had written to a boy. She had got hold of it and then shown it to Mum.

Another example that is mentioned is when a document relating to a test that is used to examine pupils' knowledge and can be sent home for parents to sign is used in a development discussion with the parents and pupil in order to indicate the pupil's overall performance, e.g. as a good pupil or a pupil with problems.

Some of the documents, such as the teacher's documentation of test results, individual development plans, action plans (if pupils have special needs) and so on are used in the personal meetings between home and school, e.g. in development discussions. The pupils say that the teachers can show their parents the results of tests or things that they have done at school, and that teachers often talk about the assessments made in the different subjects or by different teachers during these discussions. Different kinds of texts and documents can be used to "influence" emotions and identities (soft governance, cf. Foucault 1991, Rose, O’Malley and Velverde 2006), convince or prove facts or truths and in this way increase credibility, i.e. documents as agentic in the relation (cf. Latour, 2005; Atkinson and Coffey, 2011). 
Documents can also be used in other contexts and by other teachers, e.g. in a pedagogic inquiry in order to prove that a pupil needs remedial support. This means that documents even sensitive ones that can contain assessments of pupils - travel between different contexts, such as the home and parents. Pupils and parents can also have access to documents that can then be used in different ways, e.g. to gain extra help. One pupil said that her mother's attention was drawn to the poor results that were indicated in the different documents that she had to sign in order for her daughter to receive remedial help. In other words, different types of documents function and "act" and can create a powerful version of social reality in order to reach a specific goal (Atkinson and Coffey, 2011).

According to the pupils, the documents that they distribute between home and school and that they talk about in the interviews serve to inform and influence parents and ensure that they have been informed in order to access the necessary resources etc. One pupil thought that the adults "gossiped" about them.

Documentation, which is sometimes also produced by the pupils themselves after receiving instructions from the teacher, creates images of the children as "someone": a clever pupil, a pupil with reading and writing difficulties etc. Anna, who appreciates development discussions and the collection of documents relating to performance, says:

\footnotetext{
Anna: They have some forms and talk about my performance in class, my schoolwork and such things. Then I get to know what I am like in school - if I've done something well, have got a star or something like that./.../ The teachers also bring a lot of scores and so on. And some tests. Interviewer: Okay, are you doing well in school then? Anna: Yes, kind of. And I now know what I can do better.
}

In this example, Anna clearly appreciates her teachers' use of certain documents to show and tell her that she is doing well at school, i.e. they have the power to position and categorise her as a good pupil. The documentation helps her to see who she is and how she is doing (sic!). "Finding out who one is" can be interpreted as an understanding of being categorised, which in cases of negative criticism can be experienced as less pleasant. In this way, documents about pupils contribute to creating and re-creating their identities (cf. Foucault, 1991; Butler, 1997; Rose, O`Malley and Velverde, 2006; Andréasson and Asplund Carlsson, 2011).

The pupils' narratives about documentation and its use can be understood as a way of making the activity and its actors visible, e.g. teachers and other professionals in school, and indicate what they do and what they want to or have achieved. However, in the main, their narratives 
highlight the creation of images and categorisations that stand firm and are forwarded. In this context, documents are thought to be used in the interaction with the home and to govern children to understand themselves and how they perform, and to provide guidance by the setting up of targets, e.g. via logbooks.

\section{Discussion}

The significance of documentation for schoolchildren, with its various purposes and applications for different actors, is complex. The increase in documentation, not least through new possibilities to produce and spread documents digitally, is now regarded as a "natural" part of school life, where there is also a requirement for collaboration between the home and the school. This study shows that "there is a heterogeneous body of documents which fulfil different purposes, forms and functions in the relation between home and school". Vilka

\section{Vilka problem loses med detta-uppfylla lp krav, uppdatera, hjälpa} banren, uppmana ban och fld, tala om vad man gör, kontroll, samverkan. Barnens roll är att upprätthålla och de enda som finns i båda världar, se kommentar

In the encounter in the intermediate sphere (Mayall, 2002) between the school and the pupils, the home and the school, for example in different types of discussion and documentation, the school largely revolves around making certain norms visible and documenting progress, i.e. use a "documenting gaze". This can include controlling, assessing and comparing, pointing to individuals' strengths and weaknesses, and be backward- or forward looking. The role of documentation in the relation between home and school can be important in terms of transparency, participation and influence. It can be productive by consolidating and supporting what has been decided on, i.e. constitutes inscriptions (cf. Alasuutari, Markström and Vallberg-Roth, 2014) and be linked to children's rights, e.g. in the form of support. However, it can also be a controlling, regulating and effective tool, even in situations that do not appear to contain any decision-making or educational elements. What does it mean that pupils are documented, take part in the documentation of themselves and are used a messengers and consumers of documents? What power do children have to control this documentation, and how does it travel between the different actors in time and space?

Children's understanding of documentation and their role in the documentation that comes across in this study is largely about creating and re-creating different actors' narratives about 
the children and their school day. The children balance between producing, distributing, delivering, explaining/translating, sifting information, making things visible and being exposed to parents and teachers. Their utterances/interviews show that the children perceive themselves as both objects and subject in the processes of documentation in the intermediate sphere between home and school.

The results of this study thus show the importance that documentation has for the images that are both created and passed on, and also how it explicitly and implicitly invites and governs children (and maybe also the parents) to reflect on, understand and regulate themselves (cf. Foucault, 1991). In this context, documents and documentation acquire meaning and contribute to agency, e.g. to behaviour, prerequisites for relations and roles in a process of subjectivity (Butler, 1997). The agency of documentation is central for initiating, producing and spreading different messages that in turn create agency in this process, i.e. materially mediate practices of general ordering (Atkinson and Coffey 2011). Documentation can also travel between different actors and contexts, follow a pupil, and actually begin to live its own life by the re-creation of a "narrative" and a delayed feedback that can occur in new contexts.

Documentation can have an ideological influence and "prove" facts or truths, i.e. documents as agentic in the relation (cf. Latour, 2005; Atkinson and Coffey, 2011). The effectiveness of "the pen" and of documents is incorporated into our everyday lives and can be seen as an influence that is more or less invisible and is seldom opposed. However, as shown in this study, it can become visible in the face of violation or resistance, e.g. when pupils do not fulfil their obligations to distribute documents, or do not want to contribute to documentation, and in this way create new behaviour and agency.

\section{References}

Alasuutari M, Markström A-M and Vallberg Roth A. 2014. Assessment and Documentation in Early Childhood Education. London: Routledge.

Andréasson I, Asplund Carlsson M. 2011. Elevdokumentation: om textpraktiker i skolans värld. Stockholm: Liber.

Atkinson P, Coffey A. 2011. Analysing Documentary Realities. In D. Silverman (Ed.), Qualitative Research 3rd Edition (77-92). London: SAGE Publications Ltd.

Ayton K, Markström, A-M. 2013. School Inspection complaints: parents's safeguarding their children's education? ERNAPE- conference in Lisboa, Portugal, September 2013. 
Bartholdsson, ^. (2012). Shaping the Good Pupil- Socialization, Nomralization and Benevololent Governing in Two Swedish Scholls. International Journal for CrossDisciplinary Subjects in Education, 2(2), 1029-1035.

Bodén, L. 2013. Seeing red? The Agency of Computer Software in the Production and Management of Students' School Absences', International Journal of Qualitative Studies in Education, 26 (9): 1117-1131.

Castelli S, Pieri, M. 2007. Mobile-mediated home-school partnership: attitudes and expectations of teachers, parents and students. International Journal about Parents in Education, 1, 182-187.

Deslandes R, Cloutier, R. 2002. Adolescents Perceptions of Parental Involvement in Schooling. School Psychology International, 23(2), 220-232.

Edwards R, Alldred, P. 2000. A typology of parental involvement in education, centring on children and young people negotiating familisation, institutionalisation and individualisation. British Journal of Sociology of Education, 21(3) 435-455.

Foucault M. 1991. Governmentality. I: G. Burchell, C. Gordon, \& P. Miller (Eds.). The Foucault Effect: Studies in Governmentality. With two Lectures by and an Interview with Michael Foucault, p. 87-104. Chicago: University of Chicago Press.

Harcourt D, Perry B, Waller, T. 2011. Researching young children's perspectives: debating the ethics and dilemmas of educational research with children. New York: Routledge.

James A. 2007. Giving voice to children's voices: practices and problems, pitfalls and potentials. American Anthropologist, 109:206-272.

Jørgensen M, Phillips, L. (2002). Discourse Analysis as Theory and Method. London: Sage.

Latour B. 2005). Reassembling the Social: An Introduction to Actor-Network-Theory. New York: Oxford University Press.

Lawson, M.A. 2003. School Family Relations in Context: Parent and Teacher Perceptions of Parent Involvement. Urban Education 38(1), 77-133.

Lgr 11 (2011). Curriculum for the compulsory school system, the pre-school class and the leisure-time centre. Stockholm: Utbildningsdepartementet.

Markström A-M. 2009. The parent-teacher conference in the Swedish preschool. A study of an ongoing process as a "pocket of local order". Contemporary Issues in Early Childhood, 10 (2), 122-132.

Markström A-M. 2011."Soft governance" i förskolans utvecklingssamtal. Educare, 2011:2, 57-75.

Markström A-M. 2013. Children's perspectives on the relations between home and school. International Journal about Parents in Education,7(1), 43-56.

Mayall B. 2002. Towards a Sociology of Childhood. Thinking from Children's Lives. Buckingham: Open University Press.

Power M. 1997. The Audit Society: Rituals of Verification. Oxford: Oxford University Press.

Rose N. 1999. Powers of Freedom. Reframing Political Thought. Cambridge: Cambridge University Press.

Rose N, O’Malley P, Valverde M. 2006. Governmentality. Annual Review of Law and Social Science, 2, 83-104. 
Sarmento T, Freire, I. 2012 Making school happen. Children-parent-teacher collaboration as a practice of citizenship. Education sciences, 2(2): 105-120.

Vyverman V, Vettenburg N. 2009. Parent participation at school. A research study on the perspectives of children. Childhood, 16 (1), 105-123. 